\title{
Freedom of Religion in Islam and Buddhism: A Comparison Study of the Barriers That Determines the Freedom of Religion
}

\author{
Mutsalim Khareng ${ }^{1}$, Jaffary Awang ${ }^{1}$, Zaizul Ab. Rahman ${ }^{1}$, Rohanee Machae ${ }^{2}$ \& Khaidzir Ismail $^{3}$ \\ ${ }^{1}$ Theology and Philosophy, National University of Malaysia, Malaysia \\ ${ }^{2}$ Shariah, National University of Malaysia, Malaysia \\ ${ }^{3}$ School of Psychology, Faculty of Social Sciences and Humanities, National University of Malaysia, Malaysia \\ Correspondence: Mutsalim Khareng, Department of Theology and Philosophy, Faculty of Islamic Studies, \\ National University of Malaysia, Malaysia. Tel: 60-12-267-8209. E-mail: habba_yabnee@hotmail.com
}

Received: July 15, 2014 Accepted: August 26, 2014 Online Published: October 30, 2014

doi:10.5539/ass.v10n22p315 URL: http://dx.doi.org/10.5539/ass.v10n22p315

\begin{abstract}
Freedom of religion is the human right that supports the individual to choose and practice a religion or belief. In the context of a multiracial society, freedom of religion should be debated openly to avoid any misunderstanding that distracts from harmonious social living. This research is a comparative study that focuses on the principles that determine the barriers of freedom of religion between Islam and Buddhism. For means of accuracy and relevancy of information, the researcher adopts the content analysis approach of the primary references in Islam and Buddhism. The research concludes that both religions share a similar scope of freedom of religion and declare freedom as a right that should be accorded to all. Both religions prioritize the social interest as the main benchmark in discussing the freedom of religion. Even though Islam awards freedom of religion to all, it nevertheless maintains some differences between the rights of Muslims and non-Muslims, i.e. that Muslims do not have the right to change their religion without meriting the label of apostate.
\end{abstract}

Keywords: freedom, freedom of religion, Islam, Buddhism, harmonious social living, apostasy

\section{Introduction}

Freedom of religion is a basic human right and the aspiration of every individual and society. History shows that all people want their rights to be guaranteed (Al-Qardawi, 1992). Almost all countries declare the freedom of rights in the Law or Constitution (Nurhafilah, 2007). In international law, the Universal Declaration of Human Rights 1948 states a variety of human rights. Among such rights are freedom, justice, fighting for justice, fighting for the truth, right of the minority, an organized economy and development, copyright, social peace, family, women's right, education, freedom of expressions, and religious freedom among others (Adnan, 1996).

The freedom of religion is the $18^{\text {th }}$ item of the Declaration of Human Rights are protects freedom of thought and belief. It asserts that no one should be subject to discrimination based on religious beliefs. There have been countless debates relating to human rights since the earliest times of human existence and civilization. This is because of the oppression of that right has resulted in crisis that can ruin harmonious social living (Khadhar, 2010). Therefore, it can be said that freedom of religion is among the most important rights awarded by each religion. This research focuses on identifying the freedom of religion in terms of the principles that determine the barriers of the freedom of religion in Islam and Buddhism.

\section{Research Background and Problem Statement}

The belief that the truth of any religion is a relative truth that places any religions at an equal position and a valid journey to meet the same God is termed religious pluralism. Based on the chronology of history, the idea of religious pluralism is shown to have a broad influence whether in the West or the East, including in the Muslim world. Pluralism shows that the great world faiths symbolize distinct perceptions and conceptions by having distinct responses to the true or the vital from the main cultural different. In addition, the idea claims that the transformation of human existence from self-centredness to reality centeredness is clear, at this point as human reflection can express, it is too much the same extent.

Besides Hick (1987) this idea is also discussed by Smith, W. C. who highlights religious pluralism with the 
slogan World Theology (Smith, 1989). Knitter, P. also commented about this idea and asserts that it, "cannot be said that religion which one is better that the other." It does not mean, "All religions are relative-that is limited, partial, incomplete, one way of looking at thing. To hold that any religion is intrinsically better than another is felt to be somehow wrong, offensive, narrow-minded," and also mean "deep down, all religions are the same-different paths leading to the same goal" (Knitter, 1985). In summary, religion is the relative human perception towards the ultimate God, and with this relativity, all religions cannot claim or believe their religions are the real truth compared to others. Religious pluralism is practiced by liberal thinkers. The thinking here is built on believing freedom has been one of the important pillars in religion concerning the truth claim towards every religion that is believed by its believers. Pluralistic thought is a new religion that is trying to ruin religious fundamental values, including those of Islam (Adnan, 1994).

Islam clearly rejects this kind of thought, as Allah says in verses Al-Imran 3: 85, al-Maidah 5: 48, and al-Ahzan 33: 40. These verses define Islam as the highest-ranking religion compared to other religions. Islam is the only religion accepted and blessed by Allah, and al-Quran and Hadis are the main references and Muhammad (PBUH) is the messenger of Allah.

Even though Islam positions itself as the highest-ranking religion compared to other religions, recently, an alarming debate among Muslim and non-Muslim scholars regarding freedom of religion has emerged. Western scholars such as Dr. Phillip Hitti, Thomas Arnold and Albert Hourani claim that Islam has been spread through roughness of war and colonialism (Zuliza, 1999). These prejudiced perceptions affect Islam negatively as it is contrasting with the war concept in Islam.

In order to show that Islam is a religion concerned very much with the issue of freedom of religion, the researcher offers a few evidences in defence against the negative perceptions that may ruin the good image of Islam. In addition, this research focuses on the freedom of religion in Buddhism, because there are a large number of Buddhist philosophers and scholars like Phramaha Thanandorn Khemapanyo (2003), Phra Brahmagunabhor P. A. Payutto (2008), and Phrakru Patumkantarakon (2011) who state that Buddhism is among the earliest religions giving the right of religious freedom.

Sri Dhammananda, V. D. K. (1992) added further that the right to freedom of religion is followed by the Buddha as explained in the Kalama Sutta;

“...it is not to accept something when you already have a thing; it has been a tradition, long time ago, or it is commonly heard...” (Phra, 2008)

The Buddhist teaching above defines Buddhism as giving the opportunity to human beings in choosing, embracing and practicing the religious customs or belief based on the decision of the healthy mind.

That statement encourages the researcher to identify and analyse in detail the freedom of religion based on the Islamic and Buddhist perspectives. The principles determining the barriers of freedom of religion are also discussed in order to identify the existence of similarities and differences between Islam and Buddhism so that the findings can be serve as arguments for inquiries regarding the freedom of religion, especially in Islam.

\section{Research Methodology}

Research methodology is very important in guiding the researchers on proper data collection. Explanation of the methodology will ease the researcher in effecting a systematic research. This research analyses the works related to the issue of freedom of religion produced by academicians. For this purpose, the research adopts the content analysis method, which focuses on the materials from the mass media such as journals, books, written reports and other materials. This method can be used in various fields including politics, social studies, management, education and others. It is very suitable in analysing the current issues and explanations of social curiosity related to the analysis.

\subsection{Freedom of Religion in the Islamic Perspectives}

The use of the word freedom or hurriyyah in Arabic offers various meanings. Among such meanings is that it is an antonym for slavery. Islamic teaching claims that all people are born in a pure state of nature (fitrah) which they are free from any sin, suppression, inherited weakness and ancestral interruption. Even though they are born free, they do not own the ultimate free as Allah possesses the ultimate autonomy. (Ahmad, 1998). In the legal aspect, it can be defined as the freedom towards the limitless self-freedom because it is among the essential human rights. However, the freedom possessed by an individual cannot be used in trespassing others' freedom of rights (Monir, 2012). Hence, it is understood that freedom has certain limitations that follow the needs of Islamic shariah. Islam is concerned with the rights of others. Freedom in the religious scope is created to maintain the 
good relationship among believers. This means, without the freedom of religion, the good relationship between believers will not exist.

It is undeniable that Islam is the syumuliyyah (comprehensive) religion in all aspects of human life. When a person chooses to embrace a religion or an ideology and is willing to perform its obligations, that will determine his or her right and obligations.

Kamali, M. H. (1994) stated that all people have their freedom in evaluating and embracing the religion that they want without any influence from others. This is to support the idea of manifestation of personal liberty where nobody should be forced to accept any religion. In the Islamic context, freedom of religion means that there is no coercion for the non-Muslims to convert to Islam. Apart from that, they are also allowed to practice their religious customs and rituals. Moreover, Muslims and non-Muslims have the rights to spread, protect and fight for their religions from any harmful acts or libel (fitnah) taken by anybody. Freedom of religion is a term that shows each human being's right to choose their belief. In that case, nobody has the right to force others to believe in any religion. In contrast, everyone has the right to believe in something based on his or her own decision (as-Saidi, 1999). According to I. Badwi (1980), the freedom in practicing the religion is the ability of human beings to declare their religion and show their belief (akidah) while the freedom to belief (akidah) is the ability to embrace, or not to embrace, any religion along with the ability to change or not to change their belief (akidah).

Even though Islam is the highest ranking religion compared to other religions, as Allah says in the verse Ali-Imran 3: 19, it still recognizes the existence of other religions and gives them the right to live as well as respect other religious beliefs. As Allah says in the verse al-Baqarah 2: 256 that Islam gives the right to all people to choose their belief without any force. Islam takes this libertarian attitude because religion depends upon faith, will, and commitment, not compulsion. Forced faith is no faith at all. Allah states that if He had willed, He could have made all the people believers. However, had that been the case, the faith of the believers would not have been tested, as Allah says in the verse Yunus 10: 99,

"If it had been thy Lord's Will, they should all have believed, all who are on earth! Wilt thou then compel mankind, against their will, to believe!"

Ultimately, Allah states that it is His will whether non-Muslims accept Islam or not. According to S. Abdul Ghani (2001), freedom of religion in Islam is not based on the freedom concept, but it is based on the special significance in the shariah laws that complement the principles that there is no force in embracing any religion and laws that have the social interest in avoiding Islam from being mocked. Thus, freedom of religion has been consistently enunciated as a norm of the shariah regardless of considerations of time and circumstance (Kamali, 1994). It is understood here that Islam has a concept of syumuliyyah (comprehensive) which covers all aspects of human life. This means that people who have chosen any religion or ideology are prepared to perform the task of that religion or ideology.

\subsection{Freedom of Religion in the Buddhism Perspectives}

The good freedom in Buddhism is the freedom that is translated from the moral aspect. It refers to the heart being free from lust (Anuttara samyak sambodhi). Nevertheless, if the believers cannot bear the lust, they will experience sadness as stated by Buddha "Sampang Paravasang thukkhang" which is slavery towards all fake elements (the world) will also feel the sadness. Conversely, "Sampang Issariyang Sukhang" is the real happiness where the heart is calm and free from those fake elements. Buddhism concerns itself much with the freedom of religion. In Buddhism, the good and evil have been stated clearly in the religion, while humans have been given the free mind in choosing whatever they like. The same goes to the religious issue, where Buddhism gives the right to its believers in choosing, identifying and analysing the truth of a belief without any force. In order to ensure that the religion is the truth, each believer should decide based on their healthy mind and knowledge, and not choose or embrace a religion based on a corrupt state of mind (Phrakru, 2011).

Freedom of religion in Buddhism refers to the teaching of the Buddha in the Tripitaka that contains ten lessons on the healthy mind in evaluating the truth of certain beliefs in Kalama sutta kankhaniyatthana; (a.) be not led by report (Ma Anusasawen), (b.) be not led by tradition (Ma Paramuprai), (c.) be not led by hearsay (Ma Itikirai), (d.) be not led by the authority of texts (Ma Pithoksamupathanen), (e.) be not led by mere logic and argument alone (Ma Takukahettu), (f.) be not led by inference (Ma Nayahettu), (g.) be not led by considering appearances (Ma Akorpariwitkuken), (h.) be not led by the agreement with a considered and approved theory (Ma Thitthinichamanokkukhanuthitaya), (i.) be not led by seeming possibilities (Ma Phapuphrutai) and (j.) be not led by the idea, "this is our teacher" (Ma Sammanornokhruti) (Phra, 2008). 
The Buddhist follow few attitudes of a good advisor and preacher which are; (a.) there is no bad talking, fighting and blaming other religions, in addition, the Buddhist always uses the healthy mind in arguing for religious truth (Anupanatho), (b.) do not use oppression and do not use physical strength to force people to embrace the religion (Anupakhato), (c.) have good moral behaviour (Patimokukhae sangvarai), (d.) live modestly without luxury (Pattassaming mattanyata), (e.) sit and sleep in quiet and calm plce (Pantang sayanasnang) and (f.) educate the heart to be strong (Athicittae ayokho) (Phramaha, 2003). This attitude proves that Buddhism gives the opportunity to its believers to identify, choose and embrace the religion or belief based on their self-confidence, not by forceful act.

\subsection{Principles That Determine the Barriers of the Freedom of Religion between Islam and Buddhism}

It cannot be denied that all humans have rights since they were born, but that right does not mean that they can do whatever they like while oppressing others. To avoid from any distraction in harmonious social living, a large number of Muslim scholars like A. Hasan al-illi (1974), A. as-Saidi (1999), A. Wafi (n. d.), W. al-Zuhai (n. d.) highlighted three ways of protecting the freedom of religion by Islam. The first way is as stated in the verse al-Baqarah 2: 256, nobody should be forced to leave their religion and accept Islam. By following this principle, the Muslim leaders have allowed their citizens to practice their own religion as long as they paid the poll-tax (jizyah) and follow the respective government. The jizyah is also regarded as a replacement for them to be excused from the military service. The second way is based on the verse an-Nahl 16: 22, al-Ankabut 29: 46, al-Baqarah 2: 111 where Islam promote the freedom of individual to spread their religion through comprehensive reasoning and argumentation. Hence, Muslims should use polite reasoning in attracting others to embrace Islam. Other than that, Muslims should also allow the believers to apply the same strategies. The last way listed that Qur'an acknowledges the custom that the real faiths means it does not come from the simulation and total devotion to the customs, but it comes from the confidence and belief. Those statements proved that Islam criticized the pre-Islamic practices and rituals that encouraged blind simulation of ancestral precedents as their ultimate belief.as in the verse of Qur'an al-Baqarah 2: 170 (Kamali, 1998).

Freedom of religion in Islam portrays the right of an individual. Moreover, Islam protects the freedom of religion completely and Muslims do not have the right to oppress or prohibit others from choosing their belief as well as practicing the religious customs that they believe in. Besides, Islam encourages the opportunity to engage in dialogue with other religions. Islam encourages religious discussion and hopes that Muslims will always be genuine and active when having the dialogue with the non-Muslims. In Islam, any discussion conducted by using clear, rational and knowledgeable arguments may allow people to follow the truth freely, without any force in asking them to embrace Islam.

Islam regards the embracing of Islam by forceful acts as dishonest faith (iman). Belief and satisfaction towards a religion is the condition for valid faith (iman). That means, if someone forcefully embraces a religion, honesty will never exist.

Freedom of religion in Islam involves the element of choice, not force. Islam teaches the human being to use the rational evidence and the right speech as the pillar in spreading the religion, considering and thinking as well as calling for rejecting those who came without any knowledge or evidence (Wafi, n. d.). The decision to choose a religion or belief should come from understanding, intelligence and knowledge not from believing a religion based on tradition by merely following ancestral belief.

Evidently, Islam gives the right to human beings in choosing the religion or belief, but that does not mean that Muslims can simply change their religion. The freedom of religion is only valid for the non-Muslims to choose and believe as well as practice their religious customs. The changing of religion (from Islam to the other religions) in Islam is called apostasy as Allah says in the verse al-Nisa 4: 137.

The verse clarifies that Islam prohibits Muslims from leaving Islam. The issue of apostasy cannot be discussed under the scope of freedom of religion as discussed earlier, but under the laws related to Muslim peace and preserving Islamic laws (Fuad, 2002).

The principles that determine the barriers of freedom of religion in Buddhism refer to the teaching by the Buddha in the Tripitaka that contains the ten teachings in Kalama sutta kankhaniyatthana as discussed earlier. The free thinkers or the true-seekers community is among the people who asked guidance from Buddha in making decision on which religion to believe in. This is stated in Kalama sutta kankhaniyatthana where these young free thinkers are facing confusion in their lives on which religion to choose as each of them has different ways of approaching the people. After they had the discussion with Buddha, he gave them some guidelines on how they can choose their own religion. According to Buddha, people who do not believe in Dhamma will not go to hell as some people considered Dhamma as the only teaching of value in the world. Therefore, Buddha has 
highlighted few elements to be looked on by people before choosing the religion. Firstly, Buddha told them that in embracing a religion, faith is the only element to be considered. People should understand the religion fairly at the first place. In other words, blind faith and absolute devotion should not be involved as the ultimate elements in choosing a religion. This statement suggested that the teaching of Buddha is very rational to people. Besides, Buddha also advised the people to choose the religion freely, without being influenced by the frightened idea of getting the horror punishment after their death. Buddha also claimed that in embracing a religion, people must have personal and rational principle, instead of being guided by the law listed by the authorities or supernatural powers (Payutto. 2008).

In Buddhism, human beings have the complete right to think whether to accept or reject a religion. Human beings are free to investigate something and accept it if that thing is equal to their awareness. Based on the statement by Sri Dhammananda, V. D. K. (1992), Buddha asked people to be independent by using their intelligence and free determination. As Buddha said, "You can become your master". In the other words, Buddha did not want people to regard him as the "Enlightened Teacher", where they cannot choose other god to be worshipped. Buddha also wanted the people not to worship him blindly with the promises of they can go to heaven or gain Nirvana without doing other good deeds. This gives the idea that no one should be the slaves of any religious teacher if they really understand the principles of their believed religion. Buddha wanted the people to be independent in reaching their ultimate salvation as no religious teacher can help them to do that. However, they still need to respect the religious teacher. The religious teacher is only a guidance who will tell them what to do in achieving it. This means, nobody will be saved by anybody as they need to be saved on their own. They should be free in achieving their ultimate freedom from mental impurities and worldly suffering. In brief, with the guidelines given by the religious teacher, people should be independent in reaching their ultimate freedom (Ven, 1992).

In Buddhism, the monks and their students do not possess the right to force others to embrace their religion, but they play the role in explaining the religious inquiries. After a clear explanation, the decision whether to embrace or not to embrace Buddhism depends on an individual. In other words, Buddhism gives the freedom to human beings in choosing whether to be an atheist, to leave Buddhism, or any other type of decision without force.

The analysis of the principles that determine the barriers of the freedom of religion indicate that there are Islamic and Buddhist perspectives. However, there are also some differences in the principles of freedom of religion between Islam and Buddhism. In Buddhism, based on the teaching of the Buddha on the freedom of religion prove that there is no force in choosing a religion and everyone has the right to choose, practice and spread their religions, as well as the right to change the religion or become an atheist. It can be said that this right is balanced with the declaration in the constitutions of most of the countries, where all believers have the equal right to embrace, practice as well as spreading the religions, or to remain free of any religion.

In Islam, even though the issue of freedom of religion is very important, but there are always inquiries by the non-Muslims regarding the issue why Islam set the death penalty to Muslims who leave Islam. Several derivatives of the term riddah are used in the Qur'an. The usages appear closest to "apostasy". Riddah literally means "turning back". Murtad, the active participle from istidda (to turn back, to renounce), means "one who turns back". In Islamic law, riddah is understood to be reverting from the religion of Islam to kufr, whether by intention, by an action that would remove one from Islam, or by a statement, be it in the form of mockery, stubbornness or conviction. Jurists of the Sunni legal schools Hanafi, Maliki, Shafi'I and Hanbali, classify apostasy in three categories; belief-related, action-related and utterance-related (Saeed, A. \& Saeed, H. 2004).

In this issue, most Muslim philosophers come with their arguments and opinions to defend the purity of Islam for instance, Muhammad Mutawalli al-Sha'rawistated in his writing entitled "You Asked and Islam Answers" that everyone has the right to choose, embrace and practice any religions, but once they embraced Islam, that freedom is invalid as they are tied to Islam. If someone wanted to leave Islam, he or she will be punished including the death penalty. In summary, everyone has the right to choose and embrace Islam, but after that, they are not free to leave Islam. According to Lewis, B. limitation on religious freedom, from the Islamic perspective, is that while individuals have the freedom to accept or reject Islam, freedom of worship and belief, the majority of classical scholar have argued that the shariah does not permit a Muslim to deny or denounce his/her religion (apostasy) once he/she has accepted Islam. From a Muslim religious point of view, this discrepancy is both logical and proper. To promote the true faith is a divine commandment. To abandon it or to persuade another to do so is both a major sin and a capital crime (Lewis, 1993). In his monograph, The Punishment of Apostasy in Islam, S. A. Rahman argues that not only is the Qur'an silent on the punishment for apostasy, but hadith which indicate punishment by death have a weak chain of transmission. Some have argued that although apostasy is a sin in Islam, it carries no punishment, while others have argued that the penalty for apostasy is in the Hereafter 
only (Ahmad, 1998). In light of this, it is not surprising to find a number of prominent scholars, across the centuries, subscribing to the view that apostasy is not a punishment offence. According to Mahmasani, the death penalty was meant to apply, not to simple acts of apostasy from Islam, but when apostasy was linked to an act of political betrayal of the community. The Prophet Muhammad (PBUH) never killed anyone solely for apostasy. This being the case, the death penalty was not meant to apply to a simple change of faith but to punish acts such as treason, joining forces with the enemy and sedition (Kamali, 1994). In this case, it is understood that the barriers of freedom of religion in Islam shows the difference of rights among the Muslims and non-Muslims. A person, who has embraced Islam, does not have the right to change the religion or become the atheist, as the act can be regarded as a crime that can lead to punishment.

\section{Conclusion}

As a whole, the research findings suggest that the definition of freedom of religion whether from the Islamic or Buddhist perspective share a similar scope which is the freedom to embrace, practice and spread the religion. Both religions declare the freedom of religion as the right of everyone. Both religions prioritize the social interest as the main benchmark in talking about the freedom of religion. In the other words, if the practice or the spreading of religion affects the social interest negatively whether in relation to health, safety or harmonious social living. It can be punished by the government as the reason for protecting the social interest. There are different sources that prove the fact of the freedom of religion. The declaration of the freedom of religion in Islam is based on the al-Qur'an and Hadith by Prophet Muhammad (PBUH). Whereas, the certification of the religious freedom in Buddhist perspectives are focused on the philosophy from the Buddha's teaching. In conclusion, the statement that Islam is spread by war and colonialism is not true as it contrasts with the freedom of religion promoted by Islam. In fact, the toleration in Islam gives the right to the non-Muslims in practicing their belief even though they are leading far from the truth of Islam.

\section{References}

Adnan, A. (1994). Religious Pluralism in Christian and Islamic Philosophy: The Thought of John Hick and Seyyed Hossein Nasr. Curzan: Japan Society Publications.

Adnan, B. N. (1996). Human Right in Islam and Western Society. In Religion and Dialogue among Civilizatios. Jakarta: Paramadina.

al-Badw, I. (1980). Daaim al-ukm fi Shariah al-Islamiyah wa al-Nizam al-Dusturiyah al-Muassirah. Beirut: Darul al-Fikr al-Arabi.

al- ${ }^{\mathrm{T}}$ Illi, A. (1974). Al-Hurriyat al-Ummah fi al-Fikr wa al-Nizam al-Siyasi fi al-Islam Dirasah Muqaranah. Dar al-Fikr al-Arabi.

al-Qardhawi, Y. (1992). Ghayra al-Muslim fi al-Mujtami al-Islami. Beirut: Mua'ssasah al-Risalah.

Al-Qur'an al-Karim.

as-Saidi, A. (1999). Al-Hurriyyah al-Fikr fi al-Islam. Mesir: Darul Ma ${ }^{\mathrm{c}}$ arif.

Fuad, S. (2002). Constitution in Islamic Perspective. Selangor: Dewan Bahasa dan Pustaka.

Ghani, S. A. (2001). The Islamic Perspective on Freedom of Religion. INSAF (Special issue on Freedom of Religion) XXX No. 2. Kuala Lumpur: Berita Publishing Sdn. Bhd.

Hick, J. (1987). Religious Pluralism. In M. Eliade (Ed.), The Encyclopedia of Religion (Vol. 12). New York: Macmillan Publication Company.

Kamali, M. H. (1994). Freedom of Expression in Islam. Kuala Lumpur: Berita Publishing Sdn. Bhd.

Knitter, F. (1985). No Other Name. London: SCM Press Ltd.

Lewis, B. (1993). Islam and the West. New York: Oxford University Press.

Monir, Y. A. (2012). Islam and Freedom of Religion in the Federal Constitution. Sungai Buloh: Gemilang Press Sdn. Bhd.

Muhammad, A. K. (2010). Huququ al-Insan abbara al-Trikh min al-asri al-Firauni ila al-asri al-Hadis Murura bil al-Tarikh al-Islami wal al-Tarikh al-urubba. Qahirah: Muassasah al-Tubaji.

Nurhafilah, M. (2007). Freedom of Religion in Malaysia: A review of Human Rights in Islam and the Universal Declaration of Human Rights 1948. Masters Dissertation, Department of Siasah Syar'iyyah, Academy of Islamic Studies, University of Malaya.

Phra, B. P. A. P. (2008). Dictionary of Buddhism. Bangkok: S.R. Printing Mass Product Sdn. Bhd. 
Phrakru, P. (2011). The Doctrine in Theravada Buddhiusm and Human Rights Promotion. Masters Dissertation, Department of Buddhist Studies, Mahachulalongkornrajavidyalaya University.

Phramaha, T. K. (2003). An Analytical Study of The Concept of Liberty in Theravada Buddhist Philosophy. Masters Dissertation, Department of Philosophy, Mahachulalongkornrajavidyalaya University.

Saeed, A., \& Saeed, H. (2004). Freedom of Religion, Apostasy and Islam. Burlington: Ashgate Publishing Company.

Smith, W. C. (1989). Towards a World Theology. London: Macmillan Press Ltd.

Sri Dhammananda, V. D. K. (1992). How to Choose a Religion. Kuala Lumpur: Buddhist Missionary Society Malaysia.

Wafi, A. (n. d.). Al-Hurriyyah fi al-Islam. Mesir: Darul Ma ${ }^{\mathrm{c}}$ arif.

Yousif, A. F. (1998). Religious Freedom, Minorities and Islam. Batu Caves: Thinker's Library Sdn. Bhd.

Zuliza, M. (1999). Freedom of Religion and Its Implications on Conversion to Islam in Malaysia. Masters Dissertation, Department of Syariah, Islamic Studies National University Malaysia.

\section{Copyrights}

Copyright for this article is retained by the author(s), with first publication rights granted to the journal.

This is an open-access article distributed under the terms and conditions of the Creative Commons Attribution license (http://creativecommons.org/licenses/by/3.0/). 